\title{
ANALISIS PEMBENTUKAN PORTOFOLIO OPTIMAL SAHAM-SAHAM JAKARTA ISLAMIC INDEX (JII) PADA MASA PANDEMI COVID-19
}

\section{ANALYSIS OF OPTIMAL PORTFOLIO FORMATION IN JAKARTA ISLAMIC INDEX (JII) STOCKS DURING THE COVID-19 PANDEMIC}

\author{
Sri Istiyarti Uswatun Chasanah ${ }^{1)^{*}}$, Syarif Abdullah $^{2)}$, Nina Valentika ${ }^{3)}$, Usfita \\ Kiftiyani $^{4}$ dan Agusyarif Rezka Nuha ${ }^{5)}$ \\ ${ }^{1)}$ Matematika, UIN Sunan Kalijaga, Jl. Marsda Adisucipto, Yogyakarta 55281, Indonesia \\ *sri.chasanah@uin-suka.ac.id \\ ${ }^{2}$ Teknik Mesin, Universitas Sultan Ageng Tirtayasa, Jl. Jenderal Sudirman KM 03 Banten 42435, Indonesia \\ ${ }^{3)}$ Matematika, Universitas Pamulang, Jl. Raya Puspiptek, Buaran, Kec. Serpong, Kota Tangerang Selatan, \\ Banten 15310, Indonesia \\ ${ }^{4)}$ Teknik Informatika, UIN Sunan Kalijaga, Jl. Marsda Adisucipto, Yogyakarta 55281, Indonesia \\ ${ }^{5}$ Matematika, Universitas Negeri Gorontalo, Jl. Jenderal Sudirman No. 06 Gorontalo 96128, Indonesia
}

\begin{abstract}
Investment is the wealth of one or more assets in the hope of future benefits. Things to consider in investing are profit and risk. So investors need to diversify their investments, which means investors need to form a portfolio through the selection of several assets so that risk can be minimized without reducing expected profits. The COVID-19 pandemic period had a big impact on the economy, especially for investors in making optimal portfolio formation. This study aims to determine the optimal portfolio formation during the COVID-19 pandemic using the Single Index Model. In this study a Single Index Model was be studied systematically and then translated into a programming. The data used are data of consistent shares included in the Jakarta Islamic Index (JII) shares over the past two years. Furthermore, these stocks are chosen which have an average return that is higher than the profits obtained if investors save their money in the bank. The results showed six JII companies included in the candidate for optimal portfolio formation. After the analysis, two shares were produced, namely BRPT with a proportion of $63.8043 \%$ and EXCL $36.1957 \%$. The proportion is expected to provide a profit of $1.57 \%$ per week and a risk of $6.06 \%$ per week. With the proportions obtained, an investment simulation was then carried out during the COVID-19 pandemic. The results of the simulation obtained a gain of $0.0771504 \%$ every week. These results are below the risk-free return of assets (SBIS) during the COVID-19-19 pandemic with an average profit of $0.087445 \%$ per week. It was concluded that optimal portfolio formation with the Single Index Model did not provide optimal benefits during the COVID-19 pandemic.
\end{abstract}

Keywords: COVID-19, investment, optimal portfolio, single index

ABSTRAK
Investasi merupakan penanaman satu atau lebih aset dengan harapan mendapatkan
keuntungan di masa yang akan datang. Hal yang harus dipertimbangkan dalam
berinvestasi yaitu keuntungan dan risiko. Sehingga investor perlu melakukan diversifikasi
dalam berinvestasi, yang artinya investor perlu membentuk portofolio melalui pemilihan
sejumlah aset sehingga risiko dapat diminimalkan tanpa mengurangi keuntungan yang
diharapkan. Masa pandemi COVID-19 berpengaruh besar dalam bidang ekonomi,
khususnya untuk para investor dalam melakukan pembentukan portofolio yang optimal.
Penelitian ini bertujuan untuk megetahui pembentukan portofolio optimal pada masa


pandemi COVID-19 dengan menggunakan Model Indeks Tunggal. Pada penelitian ini dikaji Model Indeks Tunggal secara sistematis yang kemudian dituliskan ke dalam bahasa pemrograman. Data yang digunakna adalah data saham-saham yang konsisten yang masuk dalam saham Jakarta Islamic Index (JII) selama dua tahun terakhir. Selanjutnya, saham-saham tersebut dipilih yang memiliki rata-rata return lebih tinggi dari keuntungan yang diperoleh apabila investor menabungkan uangnya di bank. Hasil penelitian didapatkan enam perusahaan JII yang masuk dalam kandidat pembentukan portofolio optimal. Setelah dilakukan analisis, dihasilkan dua saham yaitu BRPT dengan proporsi 63.8043\% dan EXCL 36.1957\%. Proporsi tersebut diharapkan memberikan keuntungan sebesar $1.57 \%$ tiap minggu dan risiko $6.06 \%$ tiap minggu. Dengan proporsi yang diperoleh, selanjutnya dilakukan simulasi penanaman modal di masa pandemi COVID19. Hasil dari simulasi diperoleh keuntungan sebesar $0.0771504 \%$ tiap minggu. Hasil tersebut berada di bawah return asset bebas risiko (SBIS) pada masa pandemi COVID-19 dengan keuntungan rata-rata $0.087445 \%$ tiap minggu. Sehingga disimpulkan pembentukan portofolio optimal dengan Model Indeks Tunggal tidak memberikan keuntungan yang optimal pada masa pandemi COVID-19.

\section{Kata kunci: COVID-19, indeks tunggal, investasi, portofolio optimal}

\section{PENDAHULUAN}

Investasi merupakan penanaman satu atau lebih aset dengan harapan mendapatkan keuntungan di masa yang akan datang (Bodie et al. 2011). Hal yang harus dipertimbangkan dalam berinvestasi yaitu keuntungan dan risiko. Sehingga investor perlu melakukan diversifikasi dalam berinvestasi, yang artinya investor perlu membentuk portofolio melalui pemilihan sejumlah aset sehingga risiko dapat diminimalkan tanpa mengurangi keuntungan yang diharapkan. Pada tahun 1952, Markowitz membuat model seleksi portofolio yang memasukkan prinsip diversifikasi. Penentuan portofolio optimal tersebut dikenal sebagai penentuan portofolio optimal model Markowitz (Elton et al. 2014). Selanjutnya, William Sharpe mengembangkan model yang dikenal dengan Model Indeks Tunggal untuk menyederhanakan perhitungan model Markowitz. Model Indeks Tunggal didasarkan pada pengamatan bahwa harga dari suatu sekuritas berfluktuasi searah dengan indeks harga pasar (Cornuejols dan Tutuncu 2007). Model analisis pembentukan portofolio sangat membantu investor dalam menanamkan modalnya agar memperoleh kombinasi keuntungan dan risiko terbaik. Anggraeni dan Mispiyanti (2020) menyebutkan bahwa model indeks tunggal dapat memberikan gambaran kepada investor untuk dapat dijadikan acuan dalam berinvestasi.

Perkembangan investasi di pasar modal saham syariah mengalami peningkatan yang cukup signifikan beberapa tahun terakhir. Hal ini dikarenakan masyarakat semakin sadar akan pentingnya pemilihan perusahaan-perusahaan yang terdaftar dalam Jakarta Islamic 
Index (JII) yang mana melakukan prinsip syariah pada investasinya. Perkembangan penelitian terhadap saham-saham JII dapat dilihat pada Talakua (2008), Wardani (2010) Purnomo dan Sularto (2016), Sari dan Suryawati (2020) serta Ulandari (2020).

Di sisi lain, tidak bisa dipungkiri ada risiko yang tidak terduga dalam berinvestasi, salah satunya adalah serangan COVID-19 yang sedang melanda berbagai negara. Di Indonesia, masa pandemi COVID-19 dimulai sejak 2 Maret 2020 ketika dua orang terkonfirmasi tertular dari seorang warga negara Jepang. Sampai tanggal 3 Juni 2020, Indonesia telah melaporkan 28233 kasus positif COVID-19. Dampak dari COVID-19 yang menyerang dunia, khususnya Indonesian tentunya sangat berpengaruh terhadap sistem perekonomian, tidak terkecuali dalam investasi saham. Dewi dan Masithoh (2020) menyebutkan bahwa hasil IHSG megalami beda signifikan, yaitu tren menurun tajam pada waktu saat terjadinya pandemi COVID-19 dibandingkan sebelum pandemi, sehingga untuk cadangan lebih baik jika diversifikasi dilakukan di real asset selain financial asset. Pada penelitian-penelitian sebelumnya belum pernah dibahas tentang pembentukan portofolio optimal saham syariah (JII) pada masa pandemik COVID-19, sehingga pada penelitian ini membahas tentang analisis pembentukan portofolio optimal saham-saham Jakarta Islamic Index (JI) pada masa pandemi COVID-19 dengan menggunan Model Indeks Tunggal. Selain perbedaan pada masa pandemi, pada model yang sama, peneliti bertujuan untuk menganalisis model secara sistematis dan menuliskannya dalam bahasa pemrograman. Penelitian ini diharapkan dapat memberikan gambaran dan keputusan kepada investor dalam pembentukan portofolio optimal pada masa pandemi COVID-19, apakah tetap melakukan diversifikasi saham ataukah cukup menabungkan uangnya di bank agar tetap memperoleh keuntungan maksimal.

\section{METODOLOGI PENELITIAN}

Pada bagian ini dibahas tentang Model Indeks Tuggal dan langkah-langkah penelitian terkait model yang dibahas dalam pembentukan portofolio optimal.

\subsection{Model Indeks Tunggal}

Berdasarkan pengamatan, Model Indeks Tunggal mengasumsikan harga suatu saham berfluktuasi searah dengan indeks harga pasar. Secara lebih spesifik, diamati bahwa kebanyakan saham cenderung mengalami kenaikan harga apabila indeks harga saham 
naik, begitu juga sebaliknya. Dengan dasar ini, return dari saham dan return dari indeks pasar yang umum dapat dituliskan sebagai berikut (Elton et al. 2014):

$$
R_{i}=a_{i}+\beta_{i} R_{m}
$$

dengan

$R_{i} \quad:$ Return saham ke- $i$.

$a_{i} \quad$ : Suatu variabel acak yang menunjukkan komponen dari return sekuritas ke- $i$ yang independent terhadap kinerja pasar.

$R_{m} \quad$ : Tingkat return dari indeks pasar, juga merupakan suatu variabel acak.

$\beta_{i} \quad$ : Koefisien yang mengukur perubahan $R_{i}$ akibat dari perubahan $R_{m}$.

Komponen $a_{i}$ merupakan bagian dari return saham perusahaan yang disumbangkan ke dalam return pasar. Nilai $a_{i}$ dapat dibagi atas dua bagian yaitu variabel acak yang menunjukkan komponen dari return saham ke-i yang independen terhadap return pasar $\left(\alpha_{i}\right)$ dan kesalahan residu ke-i $\left(e_{i}\right)$ dari $a_{i}$. Sehingga $a_{i}$ dapat dinyatakan sebagai berikut:

$$
a_{i}=\alpha_{i}+e_{i}
$$

Dengan mensubstitusikan persamaan (2.2) ke (2.1), maka diperoleh persamaan Model Indeks Tunggal sebagai berikut:

$$
R_{i}=\alpha_{i}+\beta_{i} R_{m}+e_{i}
$$

Model Indeks Tunggal menggunakan asumsi-asumsi sebagai berikut:

1. Kesalahan residu sekuritas ke- $i$ saling bebas dengan kesalahan residu sekuritas ke- $j$ atau $e_{i}$ saling bebas dengan $e_{j}$ untuk semua nilai $i$ dan $j$,

$$
\operatorname{Cov}\left(e_{i}, e_{j}\right)=0 .
$$

2. Return indeks pasar $R_{m}$ saling bebas dengan kesalahan residu untuk tiap-tiap sekuritas $e_{i}$,

$$
\operatorname{Cov}\left(e_{i}, R_{m}\right)=0 \text {. }
$$

Berdasarkan model indeks tunggal diperoleh varian dan kovarian sekuritas untuk Model Indeks Tunggal sebagai berikut:

$$
\sigma_{i}^{2}=\beta_{i}{ }^{2} \sigma_{m}^{2}+{\sigma_{e i}}^{2} \text { dan } \sigma_{i j}=\beta_{i} \beta_{j} E\left[R_{M}-E\left(R_{M}\right)\right]^{2} .
$$

\subsection{Langkah-Langkah Model Indeks Tunggal dalam Pembentukan Portofolio Optimal}

Langkah-langkah Model Indeks Tunggal dalam pembentukan portofolio optimal pada penelitian ini yaitu:

1. Menghitung return saham tiap periode waktu $\left(R_{t}\right)$. 
2. Menghitung expected return $(E(R))$ dan varian $\left(\sigma^{2}\right)$ saham.

3. Menghapus saham-saham yang mempunyai expected return di bawah return aset bebas risiko.

4. Menghitung expected return $\left(E\left(R_{m}\right)\right)$ dan varian $\left(\sigma_{m}^{2}\right)$ pasar.

5. Menghitung nilai $\operatorname{Alpha}(a)$ dan $\operatorname{Beta}(\beta)$ saham dan varian dari kesalahan residu $\left(\sigma_{e}^{2}\right)$.

6. Menghitung excess return to Beta (ERB) saham.

7. Menghitung cut- off point $\left(C^{*}\right)$.

8. Menghitung proporsi dana.

9. Menghitung expected return portofolio.

10. Menghitung risiko portofolio.

11. Menghitung keuntungan hasil diversifikasi.

12. Membandinkan dengan keuntungan jika menabungkan uangnya di bank pada saat pandemi.

13. Memberikan kesimpulan dan rekomendasi.

\section{PEMBAHASAN}

Berikut dibahas pembuktian dari langkah-langkah pada penyusunan pembentukan portofolio optimal dan hasil pembentukan portofolio optimal saham JII Model Indeks Tunggal.

\subsection{Model Indeks Tunggal dalam pembentukan portofolio optimal}

Pembentukan portofolio optimal berdasarkan Model Indeks Tunggal digunakan optimasi perbandingan antara expected return dan risiko portofolio yang dilambangkan dengan $\theta$. Portofolio optimal $P$ diperoleh dengan menarik garis lurus dari return aset bebas risiko melewati portofolio optimal di titik $P$ yang mempunyai nilai $\theta$ terbesar. Masalah optimasi Model Indeks Tunggal dapat dirumuskan sebagai berikut:

$$
\text { Maksimumkan } \theta=\frac{E\left(R_{P}\right)-R_{b r}}{\sigma_{P}},
$$

dengan kendala:

1. $\sum_{i=1}^{n} w_{i}=1$

2. $w_{i} \geq 0$ untuk setiap $i=1,2, \ldots, n$

dengan 


$$
\begin{aligned}
& E\left(R_{P}\right)=\sum_{i}^{n} w_{i} E\left(R_{i}\right), \text { dan } \\
& \sigma_{P}=\left(\sum_{i=1}^{n} \sum_{j=1}^{n} w_{i} w_{j} \sigma_{i j}\right)^{\frac{1}{2}} .
\end{aligned}
$$

Substitusi persamaan (3.2) dan (3.3) ke persamaan (3.1), didapatkan:

$$
\begin{aligned}
\theta & =\frac{\sum_{i}^{n} w_{i} E\left(R_{i}\right)-\sum_{i=1}^{n} w_{i} R_{b r}}{\left(\sum_{i=1}^{n} \sum_{j=1}^{n} w_{i} w_{j} \sigma_{i j}\right)^{\frac{1}{2}}} \\
& =\frac{\sum_{i}^{n} w_{i}\left[E\left(R_{i}\right)-R_{b r}\right]}{\left(\sum_{i=1}^{n} w_{i}^{2} \sigma_{i}^{2}+\sum_{i=1}^{n} \sum_{\substack{j=1 \\
j \neq i}}^{n} w_{i} w_{j} \sigma_{i j}\right)^{\frac{1}{2}}} \\
& =\left(\sum_{i}^{n} w_{i}\left(E\left(R_{i}\right)-R_{b r}\right)\right)\left(\sum_{i=1}^{n} w_{i}^{2} \sigma_{i}^{2}+\sum_{i=1}^{n} \sum_{\substack{j=1 \\
j \neq i}}^{n} w_{i} w_{j} \sigma_{i j}\right)^{-\frac{1}{2}} .
\end{aligned}
$$

Permasalahan di atas merupakan permasalahan quadratic problem. Dengan menggunakan metode Lagrange, maka didapatkan persamaan sebagai berikut:

$$
L=\left(\sum_{i}^{n} w_{i}\left(E\left(R_{i}\right)-R_{b r}\right)\right)\left(\sum_{i=1}^{n} w_{i}^{2} \sigma_{i}^{2}+\sum_{i=1}^{n} \sum_{\substack{j=1 \\ j \neq i}}^{n} w_{i} w_{j} \sigma_{i j}\right)^{-\frac{1}{2}}-\lambda\left(\sum_{i=1}^{n} w_{i}-1\right)-\gamma_{i} M_{i}
$$

dengan $\lambda$ dan $\gamma_{i}$ adalah pengali Lagrange dan $M_{i}$ adalah variabel slack. Permasalahan ini memiliki kondisi Karush-Kuhn-Tucker (KKT) sebagai berikut:

1. $\frac{d L}{d w_{i}}=0 ; \frac{d L}{d \lambda}=0$ dan $\frac{d L}{d \gamma_{i}}=0, i=1,2, \ldots, n$.

2. $\lambda w_{i}=0$ dan $\gamma_{i} w_{i}=0, i=1,2, \ldots, n$.

3. $\lambda \geq 0, \gamma_{i} \geq 0$ dan $w_{i} \geq 0, i=1,2, \ldots, n$.

Misalkan

$$
L=\theta_{1} \theta_{2}-\lambda\left(\sum_{i=1}^{n} w_{i}-1\right)-\gamma_{i} M_{i}
$$

dengan

$$
\theta_{1}=\sum_{i}^{n} w_{i}\left(E\left(R_{i}\right)-R_{b r}\right)
$$

dan

$$
\theta_{2}=\left(\sum_{i=1}^{n} w_{i}^{2} \sigma_{i}^{2}+\sum_{i=1}^{n} \sum_{\substack{j=1 \\ j \neq i}}^{n} w_{i} w_{j} \sigma_{i j}\right)^{-\frac{1}{2}}
$$

Turunan pertama persamaan (3.4) terhadap proporsi masing-masing saham $\left(w_{k}\right)$ sebagai berikut:

$$
\frac{d L}{d w_{k}}=\theta_{1} \frac{d \theta_{2}}{d w_{k}}+\theta_{2} \frac{d \theta_{1}}{d w_{k}}-\lambda=0
$$


Turunan pertama persamaan (3.5) terhadap proporsi masing-masing saham $\left(w_{k}\right)$ sebagai berikut:

$$
\frac{d \theta_{1}}{d w_{k}}=\frac{d\left(\sum_{i}^{n} w_{i}\left[E\left(R_{i}\right)-R_{b r}\right]\right)}{d w_{k}}=E\left(R_{k}\right)-R_{b r} .
$$

Sedangkan turunan pertama persamaan (3.6) terhadap proporsi masing-masing saham $\left(w_{k}\right)$ sebagai berikut:

$$
\begin{aligned}
& \frac{d \theta_{2}}{d w_{k}}= \frac{d\left(\left(\sum_{i=1}^{n} w_{i}^{2} \sigma_{i}^{2}+\sum_{i=1}^{n} \sum_{\substack{j=1 \\
j \neq i}}^{n} w_{i} w_{j} \sigma_{i j}\right)^{-\frac{1}{2}}\right)}{d w_{k}} \\
&=-\frac{1}{2}\left(\sum_{i=1}^{n} w_{i}^{2} \sigma_{i}^{2}+\sum_{i=1}^{n} \sum_{\substack{j=1 \\
j \neq i}}^{n} w_{i} w_{j} \sigma_{i j}\right)^{-\frac{3}{2} d\left(\sum_{i=1}^{n} w_{i}^{2} \sigma_{i}^{2}+\sum_{i=1}^{n} \sum_{\substack{j=1 \\
j \neq i}}^{n} w_{i} w_{j} \sigma_{i j}\right)} \\
&=-\frac{1}{2}\left(\sum_{i=1}^{n} w_{i}^{2} \sigma_{i}^{2}+\sum_{i=1}^{n} \sum_{\substack{j=1 \\
j \neq i}}^{n} w_{i} w_{j} \sigma_{i j}\right)^{-\frac{3}{2}}\left(2 w_{k} \sigma_{k}^{2}+2 \sum_{\substack{j=1 \\
j \neq k}}^{n} w_{j} \sigma_{j k}\right) .
\end{aligned}
$$

Substitusi persamaan (3.5), (3.6), (3.8) dan (3.9) ke persamaan (3.7), maka didapatkan

$$
\begin{aligned}
& \frac{d L}{d w_{k}}=\left[\sum_{i}^{n} w_{i}\left(E\left(R_{i}\right)-R_{b r}\right)\right]\left[\left(-\frac{1}{2}\right)\left(\sum_{i=1}^{n} w_{i}^{2} \sigma_{i}^{2}+\sum_{i=1}^{n} \sum_{j=1}^{n} w_{j} w_{i} w_{j} \sigma_{i j}\right)^{-\frac{3}{2}}\right] \times \\
& \left.2 w_{k} \sigma_{k}^{2}+2 \sum_{\substack{j=1 \\
j \neq k}}^{n} w_{j} \sigma_{j k}\right]+\left(\sum_{i=1}^{n} w_{i}^{2} \sigma_{i}^{2}+\sum_{i=1}^{n} \sum_{\substack{j=1 \\
j \neq i}}^{n} w_{i} w_{j} \sigma_{i j}\right)^{-\frac{1}{2}} \times \\
& \Leftrightarrow \frac{\left[E\left(R_{k}\right)-R_{b r}\right]-\lambda=0}{\left.2\left(\sum_{i=1}^{n} w_{i}^{2} \sigma_{i}^{2}+\sum_{i=1}^{n} \sum_{\substack{j=1 \\
j \neq i}}^{n} w_{i} w_{j} \sigma_{i j}\right)^{2}\left(E\left(R_{i}\right)-R_{b r}\right)\right]\left[w_{k} \sigma_{k}^{2}+\sum_{\substack{j=1 \\
j \neq k}}^{n} w_{j} \sigma_{j k}\right]}+\frac{\left[E\left(R_{k}\right)-R_{b r}\right]}{\left(\sum_{i=1}^{n} w_{i}^{2} \sigma_{i}^{2}+\sum_{i=1}^{n} \sum_{\substack{j=1 \\
j \neq i}}^{n} w_{i} w_{j} \sigma_{i j}\right)^{\frac{1}{2}}}-\lambda=0 \\
& \left.\Leftrightarrow \frac{\left[\sum_{i}^{n} w_{i}\left(E\left(R_{i}\right)-R_{b r}\right)\right]\left[\begin{array}{c}
\left.w_{k} \sigma_{k}^{2}+\sum_{j=1}^{n} w_{j} \sigma_{j k}\right] \\
j \neq k
\end{array}\right]}{\left(\sum_{i=1}^{n} w_{i}^{2} \sigma_{i}^{2}+\sum_{i=1}^{n} \sum_{\substack{j=1 \\
j \neq i}}^{n} w_{i} w_{j} \sigma_{i j}\right)^{\frac{3}{2}}}+\lambda=\frac{\left[E\left(R_{k}\right)-R_{b r}\right]}{\left(\sum_{i=1}^{n} w_{i}^{2} \sigma_{i}^{2}+\sum_{i=1}^{n} \sum_{j=1}^{n} w_{i} w_{j} \sigma_{i j}\right)^{j \neq i}}\right)^{\frac{1}{2}} .
\end{aligned}
$$

Sedangkan,

$$
\frac{d L}{d \lambda}=\sum_{i=1}^{n} w_{i}-1=0, \text { dan }
$$




$$
\frac{d L}{d \gamma_{k}}=M_{k}=0
$$

Dari kondisi KKT ke-2 yaitu $\lambda w_{i}=0, \gamma_{i} w_{i}=0$ dan persamaan (3.11) dan (3.12), maka didapatkan $\lambda=0$ dan $\gamma_{i}=0$. Sehingga persamaan (3.10) didapatkan

$$
\begin{aligned}
& {\left[\frac{\sum_{i}^{n} w_{i}\left(E\left(R_{i}\right)-R_{b r}\right)}{\sum_{i=1}^{n} w_{i}^{2} \sigma_{i}^{2}+\sum_{i=1}^{n} \sum_{\substack{j=1 \\
j \neq i}}^{n} w_{i} w_{j} \sigma_{i j}}\right]\left[w_{k} \sigma_{k}^{2}+\sum_{\substack{j \neq 1 \\
j \neq k}}^{n} w_{j} \sigma_{j k}\right]=\left[E\left(R_{k}\right)-R_{b r}\right]} \\
& \Leftrightarrow \psi\left[w_{k} \sigma_{k}^{2}+\sum_{\substack{j=1 \\
j \neq k}}^{n} w_{j} \sigma_{j k}\right]=\left[E\left(R_{k}\right)-R_{b r}\right] \\
& \Leftrightarrow \psi=\left[\frac{\sum_{i}^{n} w_{i}\left(E\left(R_{i}\right)-R_{b r}\right)}{\sum_{i=1}^{n} w_{i}^{2} \sigma_{i}^{2}+\sum_{i=1}^{n} \sum_{\substack{j=1 \\
j \neq i}}^{n} w_{i} w_{j} \sigma_{i j}}\right]
\end{aligned}
$$

Misalkan $\psi w_{i}=Z_{i}$, maka dari persamaan (3.13) untuk $i=1,2, \ldots, n$ didapatkan:

$$
\begin{aligned}
\psi w_{i} \sigma_{i}^{2}+\sum_{\substack{j=1 \\
j \neq i}}^{n} \psi w_{j} \sigma_{i j} & =\left[E\left(R_{i}\right)-R_{b r}\right] \\
\Leftrightarrow Z_{i} \sigma_{i}^{2}+\sum_{\substack{j=1 \\
j \neq i}}^{n} Z_{j} \sigma_{i j} & =\left[E\left(R_{i}\right)-R_{b r}\right] .
\end{aligned}
$$

Selanjutnya dengan mensubstitusikan persamaan varian dan kovarian Model Indeks Tunggal

$$
\sigma_{i}^{2}=\beta_{i}^{2} \sigma_{m}^{2}+\sigma_{e i}^{2}
$$

dan

$$
\sigma_{i j}=\sigma_{j i}=\beta_{i} \beta_{j} E\left[R_{M}-E\left(R_{M}\right)\right]^{2}=\beta_{i} \beta_{j} \sigma_{m}^{2},
$$

ke persamaan $(3,14)$, maka diperoleh:

$$
\begin{array}{ll}
Z_{i}\left(\beta_{i}{ }^{2} \sigma_{m}^{2}+\sigma_{e i}{ }^{2}\right)+\sum_{\substack{j=1 \\
j \neq i}}^{n} Z_{j}\left(\beta_{i} \beta_{j} \sigma_{m}^{2}\right)=\left[E\left(R_{i}\right)-R_{b r}\right], & i=1,2, \ldots, n \\
\Leftrightarrow Z_{i} \sigma_{e i}{ }^{2}+Z_{i} \beta_{i}{ }^{2} \sigma_{m}^{2}+\sigma_{m}^{2} \sum_{\substack{j=1 \\
j \neq i}}^{n} Z_{j} \beta_{i} \beta_{j}=\left[E\left(R_{i}\right)-R_{b r}\right], & i=1,2, \ldots, n \\
\Leftrightarrow Z_{i} \sigma_{e i}{ }^{2}+\sigma_{m}^{2} \sum_{j=1}^{n} Z_{j} \beta_{i} \beta_{j}=\left[E\left(R_{i}\right)-R_{b r}\right], & i=1,2, \ldots, n \\
\Leftrightarrow Z_{i} \sigma_{e i}{ }^{2}+\beta_{i} \sigma_{m}^{2} \sum_{j=1}^{n} Z_{j} \beta_{j}=\left[E\left(R_{i}\right)-R_{b r}\right], & i=1,2, \ldots, n \\
\Leftrightarrow Z_{i} \sigma_{e i}{ }^{2}=\left[E\left(R_{i}\right)-R_{b r}\right]-\beta_{i} \sigma_{m}^{2} \sum_{j=1}^{n} Z_{j} \beta_{j}, & i=1,2, \ldots, n \\
\Leftrightarrow Z_{i}=\frac{\left[E\left(R_{i}\right)-R_{b r}\right]-\beta_{i} \sigma_{m}^{2} \sum_{j=1}^{n} Z_{j} \beta_{j}}{\sigma_{e i}{ }^{2}}, & i=1,2, \ldots, n \\
\Leftrightarrow Z_{i}=\frac{\beta_{i}}{\sigma_{e i}{ }^{2}}\left[\frac{\left.E\left(R_{i}\right)-R_{b r}\right]}{\beta_{i}}-\sigma_{m}^{2} \sum_{j=1}^{n} Z_{j} \beta_{j}\right], & i=1,2, \ldots, n
\end{array}
$$


Misalkan himpunan dari saham optimal sebanyak $k$, maka dari persamaan (3.15) didapatkan penjumlahan dari semua sekuritas optimum sebagai berikut:

$$
Z_{i}=\frac{\beta_{i}}{\sigma_{e i}{ }^{2}}\left[\frac{\left[E\left(R_{i}\right)-R_{b r}\right]}{\beta_{i}}-\sigma_{m}^{2} \sum_{j \in k} Z_{j} \beta_{j}\right] \text {, untuk } i \in k .
$$

Selanjutnya $\sum_{j \in k} Z_{j} \beta_{j}$ dapat dieliminasi dengan mengalikan persamaan (3.16) dengan $\beta_{j}$ dan menjumlahkan sebanyak $k$ kali, sehingga didapatkan:

$$
\begin{aligned}
& \sum_{j \in k} Z_{j} \beta_{j}=\sum_{j \in k} \frac{\left[E\left(R_{j}\right)-R_{b r}\right] \beta_{j}}{\sigma_{e j}^{2}}-\sigma_{m}^{2} \sum_{j \in k} \frac{\beta_{j}^{2}}{\sigma_{e j}^{2}} \sum_{j \in k} Z_{j} \beta_{j} \\
\Leftrightarrow & \sum_{j \in k} Z_{j} \beta_{j}+\sigma_{m}^{2} \sum_{j \in k} \frac{\beta_{j}^{2}}{\sigma_{e j}^{2}} \sum_{j \in k} Z_{j} \beta_{j}=\sum_{j \in k} \frac{\left[E\left(R_{j}\right)-R_{b r}\right] \beta_{j}}{\sigma_{e j}^{2}} \\
\Leftrightarrow & \left(1+\sigma_{m}^{2} \sum_{j \in k} \frac{\beta_{j}^{2}}{\sigma_{e j}^{2}}\right) \sum_{j \in k} Z_{j} \beta_{j}=\sum_{j \in k} \frac{\left[E\left(R_{j}\right)-R_{b r}\right] \beta_{j}}{\sigma_{e j}^{2}} \\
\Leftrightarrow & \sum_{j \in k} Z_{j} \beta_{j}=\frac{\sum_{j \in k} \frac{\left[E\left(R_{j}\right)-R_{b r}\right] \beta_{j}}{\sigma_{e j}^{2}}}{\left(1+\sigma_{m}^{2} \sum_{j \in k} \frac{\beta_{j}^{2}}{\sigma_{e j}^{2}}\right)}, \text { untuk } i \in k
\end{aligned}
$$

Substitusi persamaan (3.17) ke persamaan (3.16), maka didapatkan

$$
Z_{i}=\frac{\beta_{i}}{\sigma_{e i}{ }^{2}}\left[\frac{\left[E\left(R_{i}\right)-R_{b r}\right]}{\beta_{i}}-\sigma_{m}^{2} \frac{\sum_{j \in k} \frac{\left[E\left(R_{j}\right)-R_{b r}\right] \beta_{j}}{\sigma_{e j}^{2}}}{\left(1+\sigma_{m}^{2} \sum_{j \in k} \frac{\beta_{j}^{2}}{\sigma_{e j}^{2}}\right)}\right] \text {, untuk } i \in k \text {. }
$$

atau

$$
Z_{i}=\frac{\beta_{i}}{\sigma_{e i}{ }^{2}}\left[E R B_{i}-C_{j}\right]
$$

dengan

$$
\begin{gathered}
E R B i=\frac{\left[E\left(R_{i}\right)-R_{b r}\right]}{\beta_{i}}, \\
A_{j}=\frac{\left[E\left(R_{j}\right)-R_{b r}\right] \beta_{j}}{\sigma_{e j}^{2}}, \\
B_{j}=\frac{\beta_{j}^{2}}{\sigma_{e j}^{2}}, \text { dan } \\
C_{j}=\sigma_{m}^{2} \frac{\sum_{j \in k} A_{j}}{\left(1+\sigma_{m}^{2} \sum_{j \in k} B_{j}\right)},
\end{gathered}
$$

serta

$$
\text { Cut of point }\left(C^{*}\right)=\max \left\{C_{j}\right\}_{j=1}^{n}
$$


Karena $\sum_{i=1}^{n} w_{i}=1$ dan $\psi w_{i}=Z_{i}$, maka didapatkan:

$\sum_{i=1}^{n} w_{i}=1=\frac{w_{i}}{w_{i}}$

$\Leftrightarrow w_{i}=\frac{w_{i}}{\sum_{i=1}^{n} w_{i}}=\frac{\psi w_{i}}{\sum_{i=1}^{n} \psi w_{i}}$.

Sehingga,

$$
w_{i}=\frac{z_{i}}{\sum_{i=1}^{n} z_{i}}, \text { untuk } i \in k .
$$

Selanjutnya persamaan-persamaan dari hasil pembuktian Model Indeks Tunggal di atas diterjemahkan ke dalam bahasa pemrograman menggunakan bantuan aplikasi MAPLE R2018a yang dapat dilihat pada Appendix 1. Selanjutnya, program untuk menampilkan grafik hasil perhitungan dengan Model Indeks Tunggal dapat dilihat pada Appendix 2.

\subsection{Model Indeks Tunggal dalam Pembentukan Portofolio Optimal Saham JII}

Jakarta Islamic Index (JII) adalah indeks harga saham di Indonesia yang mencakup 30 jenis saham dari emiten-emiten yang kegiatannya memenuhi ketentuan tentang hukum syariah (Huda dan Nasution, 2008). Pada penelitian ini, digunakan saham-saham yang konsisten masuk selama dua tahun terakhir pada JII. Selanjutnya digunakan model pembentukan portofolio optimal indeks tunggal. Sebanyak 25 saham JII yang konsisten masuk selama dua tahun berturut-turut yang mengindikasikan performa saham-saham tersebut cukup stabil. Saham-saham tersebut adalah sebagai berikut:

Tabel 1 Perusahaan yang konsisten terdaftar pada JII

\begin{tabular}{cclccl}
\hline No. & Simbol & \multicolumn{1}{c}{ Nama Perusahaan } & No. & Simbol & Nama Perusahaan \\
\hline 1 & ADRO & Adaro Energi Tbk. & 14 & ITMG & Indo Tambang Raya Megah Tbk. \\
2 & AKRA & AKR Corporindo Tbk. & 15 & KLBF & Kalbe Farma Tbk. \\
3 & ANTM & Aneka Tambang & 16 & LPPF & Matahari Departemen Store \\
4 & ASII & Astra International Tbk. & 17 & PTBA & Bukit Asam \\
5 & BRPT & Barito Pacific Tbk. & 18 & PTPP & PP Persero \\
6 & BSDE & Bumi Serpong Damai Tbk. & 19 & SCMA & Surya Citra Media \\
7 & CTRA & Ciputra Development & 20 & SMGR & Semen Indonesia \\
8 & EXCL & XL Axiata & 21 & TLKM & Telkom Indonesia \\
9 & ICBP & Indofood CBP Sukses Makmur Tbk. & 22 & UNTR & United Tractor Tbk. \\
10 & INCO & Vale Indonesia Tbk. & 23 & UNVR & Unilever Indonesia Tbk.
\end{tabular}




\begin{tabular}{cclccc}
\hline No. & Simbol & \multicolumn{1}{c}{ Nama Perusahaan } & No. & Simbol & Nama Perusahaan \\
\hline 11 & INDF & Indofood Sukses Makmur Tbk. & 24 & WIKA & Wijaya Karya (Persero) Tbk. \\
12 & INDY & Indika Energy Tbk. & 25 & WSBP & Waskita Beton Precast Tbk. \\
13 & INTP & Indocement Tunggal Prakarsa & & & \\
\hline
\end{tabular}

Selanjutnya saham-saham yang memiliki nilai expected return kurang dari atau sama dengan return aset bebas risiko atau $E\left(R_{i}\right) \leq R_{b r}$ tidak dimasukkan ke dalam kandidat pembentukan portofolio optimal. Hal tersebut dikarenakan apabila investor menginvestasikan dana ke bank, akan lebih menguntungkan dan tidak terdapat risiko dibandingkan dengan investor berinvestasi saham. Rata-rata besarnya return aset bebas risiko mingguan berdasarkan data SBIS (Sertifikat Bank Indonesia Syariah) selama dua tahun terakhir adalah sebesar $R_{b r}=0.00107518$. Dari 25 saham pada Tabel 1, saham yang memiliki nilai $E\left(R_{i}\right)>R_{b r}$ yaitu ADRO, BRPT, EXCL, ICBP, INDF dan WIKA. Selanjutnya enam saham tersebut dimasukkan ke dalam kandidat pembentukan portofolio optimal.

Saham-saham yang sebagai kandidat pembentukan portofolio optimal dihitung dengan menggunakan program Model Indeks Tunggal yang telah dibuat dan dibahas pada bagian sebelumnya, Dari hasil program tersebut didapatkan hasil yang disajikan pada Tabel 2, Gambar 1 dan Gambar 2.

Tabel 2 Nilai $\alpha_{i}, \beta_{i}$ dan $E R B_{i}$ saham

\begin{tabular}{lllll}
\hline No. & Perusahaan & $\boldsymbol{\alpha}_{\boldsymbol{i}}$ & $\boldsymbol{\beta}_{\boldsymbol{i}}$ & $\boldsymbol{E} \boldsymbol{R} \boldsymbol{B}_{\boldsymbol{i}}$ \\
\hline $\mathbf{1}$ & BRPT & $\mathbf{0 . 0 2 1 4}$ & $\mathbf{0 . 5 4 9 3}$ & $\mathbf{0 . 0 3 5 2}$ \\
$\mathbf{2}$ & EXCL & $\mathbf{0 . 0 1 0 4}$ & $\mathbf{1 . 6 3 9 8}$ & $\mathbf{0 . 0 0 3 9}$ \\
3 & ICBP & 0.0026 & 0.4558 & 0.0014 \\
4 & WIKA & 0.0059 & 2.2032 & 0.0004 \\
5 & ADRO & 0.0048 & 1.6411 & 0.0004 \\
6 & INDF & 0.0029 & 0.9076 & 0.0002 \\
\hline
\end{tabular}

Dengan cut off point $\left(C^{*}\right)=0.0016$, sehingga saham-saham yang mempunyai nilai $E R B_{i}>C^{*}$ merupakan saham yang selanjutnya dimasukkan dalam pembentukan portofolio optimal. Dari 6 saham JII pada Tabel 2, terdapat dua saham yang layak 
membentuk portofolio optimal, yaitu BRPT dan EXCL. Dari hasil program juga didapat pula risiko dan expected return portofolio model indeks tunggal yang disajikan pada Gambar 1 sebagai berikut:

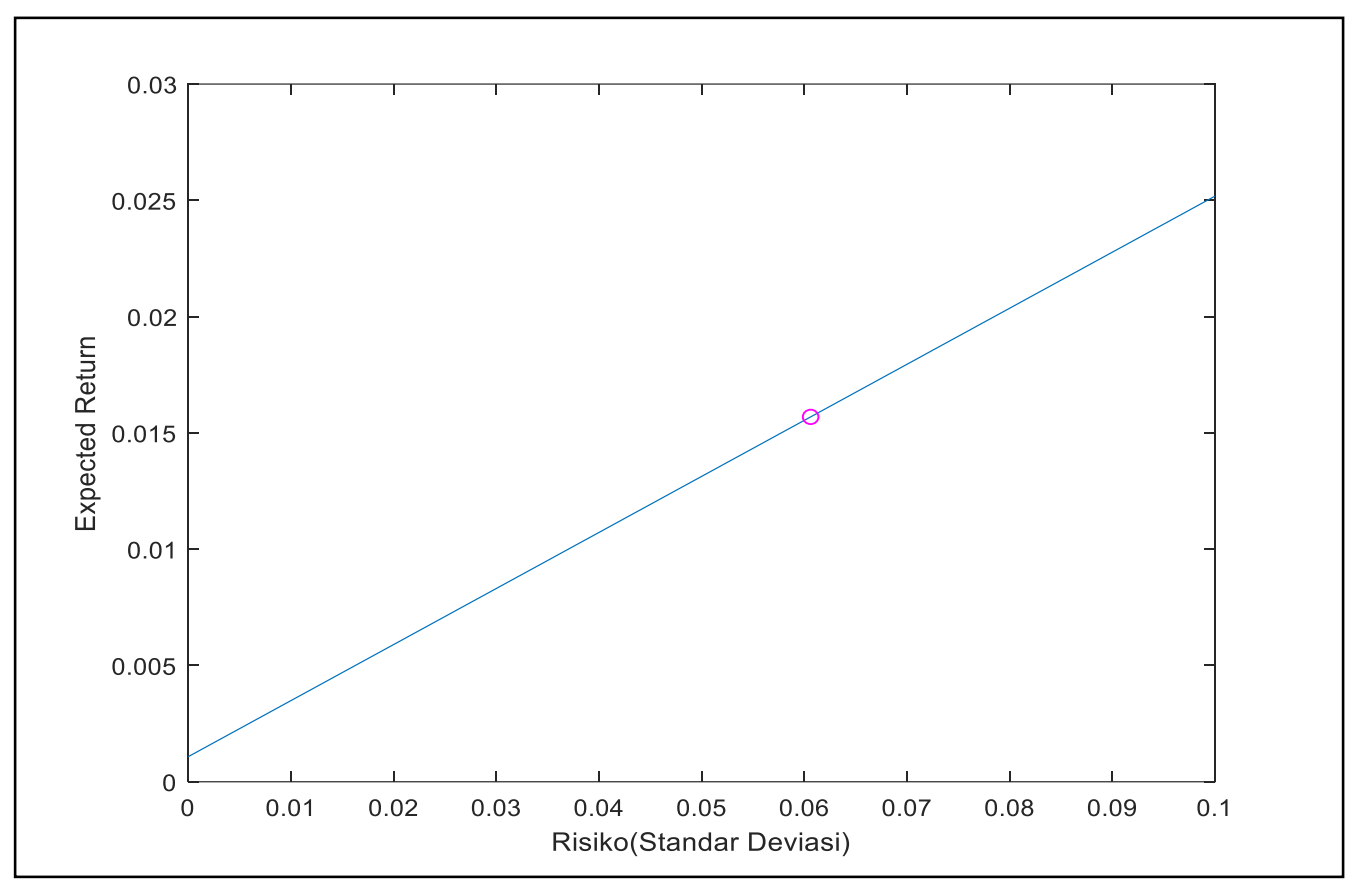

Gambar 1 Risiko dan expected return portofolio optimal

Sedangkan proporsi yang dihasilkan oleh Model Indeks Tunggal pada program yang dihasilkan, didapatkan nilai proporsi BRPT sebesar $63.8043 \%$ dan EXCL sebesar $36.1957 \%$, yang disajikan pada diagram lingkaran sebagai berikut:

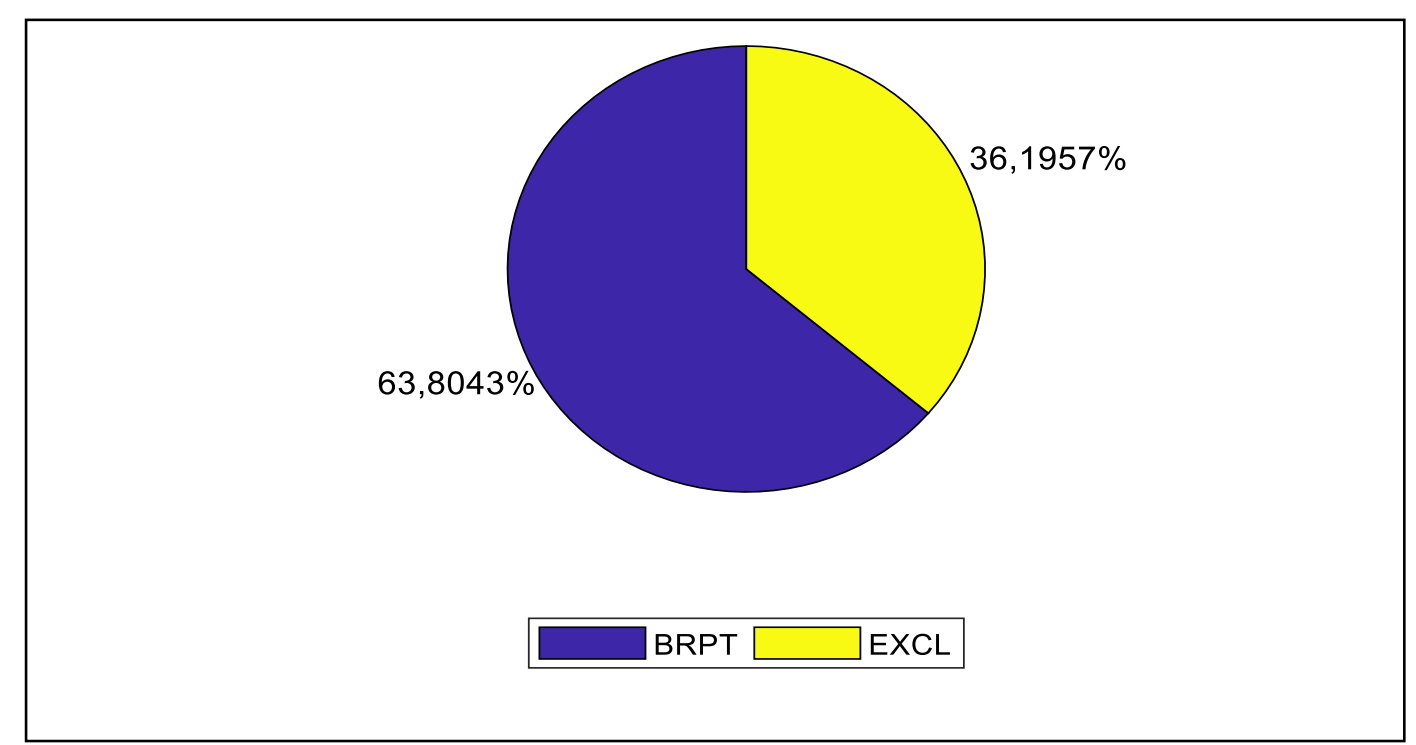

Gambar 2 Proporsi saham portofolio optimal 
Berdasarkan proporsi yang diperoleh, maka apabila investor mempunyai uang 1 Milyar, maka investor akan mengalokasikan uangnya sebesar Rp 638043000 di perusahaan Barito Pacific Tbk. dan sebesar Rp 361937000 di perusaahaan XL Axiata. Selanjutnya dengan adanya pandemi COVID-19 di Indonesia yang dimulai dari Februari, maka selanjutnya dilihat apakakah portofolio tersebut masih memberikan prediksi yang tepat terhadap keuntungan yang diharapkan investor. Grafik pada Gambar 3 di bawah ini menunjukkan return mingguan saham BRPT dan EXCL selama masa pandemi.

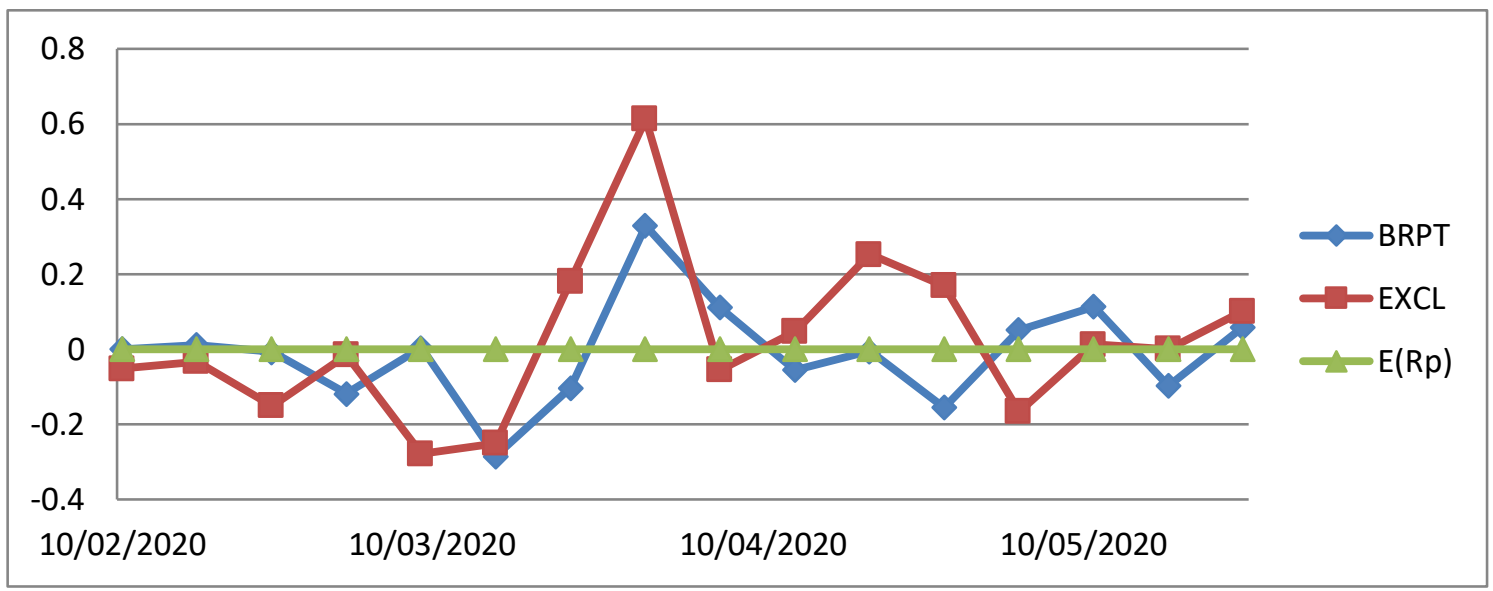

Gambar 3 Return saham BRPT dan EXCL selama pandemi COVID-19

Gambar 3 meunjukkan bahwa, apabila investor menanamkan modalnya dengan proporsi dana sebesar $63.8043 \%$ pada BRPT dan $36.1957 \%$ pada EXCL, hasil pembentukan portofolio optimal model indeks tunggal pada masa pandemi COVID-19, maka diperoleh rata-rata keuntungan mingguan adalah sebesar $0.0771504 \%$.

\section{SIMPULAN}

Simulasi dengan proporsi yang diperoleh dari model indeks tunggal memberikan keuntungan sebesar $0.0771504 \%$ setiap minggu pada masa pandemi COVID-19. Sehingga dapat disimpulkan bahwa pembentukan portofolio optimal dengan model indeks tunggal tidak memberikan keuntungan yang optimal masa pandemi COVID-19 kepada investor. Hal ini dikarenakan return asset bebas risiko berdasarkan hasil lelang sertifikat Bank Indonesia Syariah (SBIS) pada masa pandemi COVID-19 menghasilkan keuntungan rata-rata sebesar $0.087445 \%$ tiap minggu lebih besar $0.0771504 \%$ yang merupakan keuntungan portofolio saham. 


\section{DAFTAR PUSTAKA}

Anggraeni RW, \& Mispiyanti. 2020. Analisis pembentukan portofolio optimal saham dengan menggunakan model indeks tunggal (Studi kasus pada perusahaan terdaftar di indeks SRI-KEHATI periode 2016-2018). Jurnal Ilmiah Mahasiswa Manajemen, Bisnis dan Akuntansi. Volume 2, No. 1.

Bodie Z, Kane A, \& Marcus AJ. 2011. Investment. New York (US): The McGraw-Hill.

Cornuejols G, \& Tutuncu R. 2007. Optimization Method in Finance. New York (US): Cambridge Univ Pr.

Dewi CK, \& Masithoh R. 2020. IHSG and trading activities before after covid-19 outbreak. Research Journal of Accounting and Business Management (RJABM); P-ISSN: 2580-3115; E-ISSN: 2580-3131.

Elton JE, Gruber MJ, Brown SJ, \& Goetzmann WN. 2014. Modern Portfolio Theory and Investment Analysis. New York (US): Jhon Wiley Son.

Huda N, \& Nasution ME. 2008. Investasi pada Pasar Modal Syariah. Jakarta (ID): Kencana Prenada Media Group.

Purnomo AH, \& Sularto L. 2016. Analisis pembentukan portofolio yang efisien pada tiga saham syariah sektor perkebunan yang terdaftar di Jakarta Islamic Index (JII) dengan Model Markowitz. Jakarta (ID): Politeknik Negeri Jakarta.

Sari DP, \& Suryawati. 2020. Analisis Portofolio Optimal Saham Syariah Jakarta Islamic Index (JII) Periode 2015-2017. P-ISSN: 2088-9372 E-ISSN: 2527-8991.

Talakua MY. 2008. Analisis pembentukan portofolio saham kelompok JII [tesis]. Bogor (ID): Institut Pertanian Bogor.

Wardani MK. 2010. Pembentukan portofolio saham-saham perusahaan yang terdaftar di Jakarta Islamic Index (JII) [tesis]. Surakarta (ID): Universitas Sebelas Maret.

\section{UCAPAN TERIMA KASIH}

Terimakasih kepada Laboratrium Komputasi: Jurusan Matematika UIN Sunan Kalijaga, Jurusan Teknik Mesin Sultan Ageng Tirtayasa, Jurusan Matematika Universitas Pamulang, Jurusan Teknik Informatika UIN Sunan Kalijaga dan Jurusan Matematika Universitas Negeri Golontalo atas kerjasama dan fasilitas yang diberikan sehingga penelitian ini terlaksana. 


\section{APPENDIX 1}

\section{Program Metode Single Index Model}

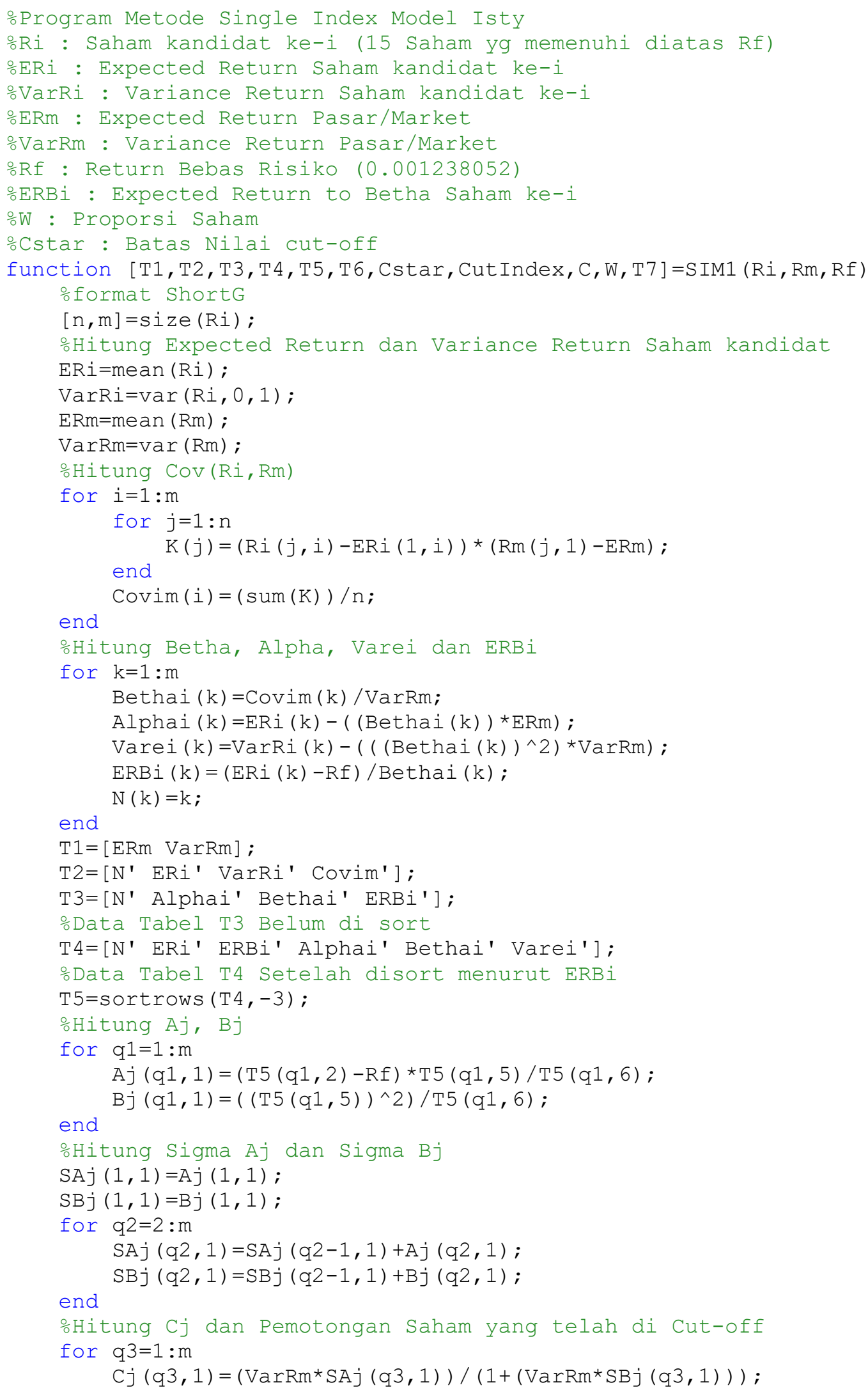




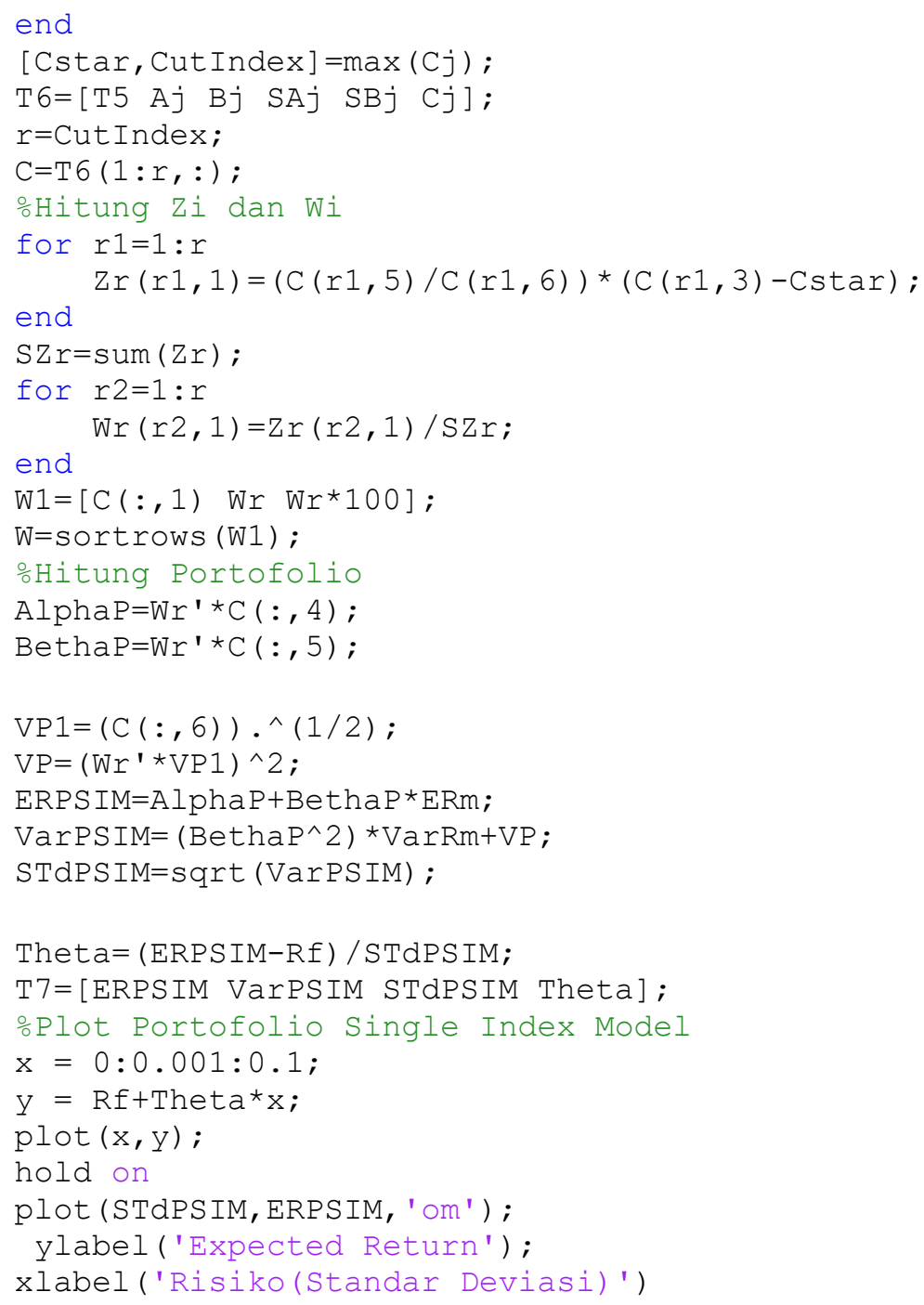

\section{APPENDIX 2}

\section{Plotting Program Metode Single Index Model}

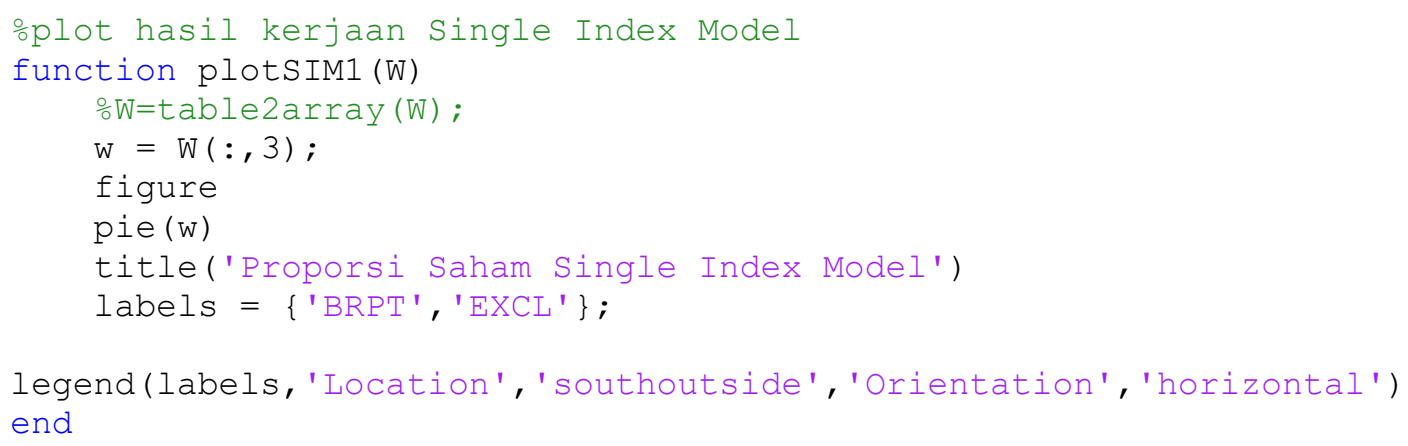

